\title{
The Use of Traditional Values for Violence in the Case of Bride Kidnapping in Kyrgyzstan
}

\author{
Naifa Rizani \\ 2015330032 \\ Mahasiswa Ilmu Hubungan Internasional, Fakultas Ilmu Sosial dan Ilmu Politik \\ Universitas Katolik Parahyangan
}

\begin{abstract}
Abstrak
Budaya, etnis, agama, dan kepercayaan dianggap memiliki kontribusi yang signifikan pada perkembangan nilai-nilai dan standar hak asasi manusia. Akan tetapi, banyak ditemukan nilai-nilai tradisi dan etnis yang mengabaikan hak asasi manusia dengan adanya elemen diskriminasi yang menyimpang. Nilai-nilai hak asasi manusia yang melekat pada kondisi sosial saat ini memunculkan perdebatan dengan pelestarian tradisi dan budaya. Tulisan ini akan membahas studi kasus dari aksi Bride Kidnapping yang menjadi etnis tradisi masyarakat Kyrgyzstan. Aksi ini merupakan bentuk kekerasan dan diskriminasi terhadap perempuan di Kyrgyzstan, yang nyatanya masih dilaksanakan hingga saat ini dibawah naungan sebuah tradisi. Di satu sisi, gerakan-gerakan penolakan terhadap pelaksanaan etnis Bride Kidnapping semakin berkembang dan mendesak pemerintah untuk melarang aksi tersebut dilakukan. Melalui tulisan ini akan dianalisa bagaimana nilai-nilai hak asasi manusia yang diakui secara universal ini memengaruhi perubahan pandangan masyarakat terhadap etnis Bride Kidnapping sehingga membentuk penolakan di masyarakat Kyrgizstan sendiri.
\end{abstract}

Keywords: tradition, human rights, Kygyzstan, discrimination

\section{Background}

The Universal Declaration of Human Rights (UDHR) was created as a common standard of all people in the world to live with fundamentally protected to achieve inherent dignity of the equal rights with foundation of freedom, justice, and peace in the world. Created within United Nations (UN) as institutes that accommodate the protection of Human Rights, it consists with 30 articles and one preamble sought to reaffirmed their faith in fundamental human rights, in the dignity and worth of the human person an in the equal rights of men and women and determined to promote social progress and better standards of life in larger

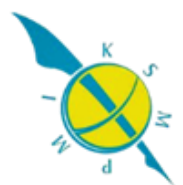


freedom. ${ }^{1}$ It was drafted by representatives with different legal and cultural background and has been accepted by all United Nations's countries in the world. United Nations Educational, Scientific, and Cultural Organization (UNESCO) become agency within UN that contribute to the development of UDHR. They have engaged in all activities of the organization and undertook the direct competence of UDHR to four sections: Right to Education, right to take part in cultural life, right to freedom of opinion and expressing including the right to seek, receive, and impart information, and right to enjoy the benefits of scientific progress and its applications. ${ }^{2}$ One of agenda within UNDHR that UN wants to achieve is fight against discrimination and any kind of intolerance. Discrimination is seen as the most fundamental cause of human rights violations and frequently sustained through the use of violence. From United Nations Human Rights Committee (UNHRC) has stated that discrimination should be understood to imply any distinction, exclusion, restriction or preference which is based on any ground such as sex, race, color, language, religion, political or other opinion, national or social origin, property birth or other status, and which has the purpose of nullifying or impairing the recognition, enjoyment or exercise by all persons, on an equal footing of all rights and freedoms. ${ }^{3}$

Though fighting discrimination should be a way to promoting human rights and fundamental freedoms, it somehow becomes problem in the context of preserving traditional value. In several societies that have strong conviction in their culture and tradition, often intersect with universally accepted human rights values. As culture and tradition existed before the human rights declaration, it becomes

\footnotetext{
${ }^{1}$ Universal Declaration of Human Rights, United Nations, accessed October 20 2017, http://www.un.org/en/universal-declaration-human-rights/

2 UNESCO and the Declaration, United Nations Educational, Scientific, and Cultural Organization, accessed on October 20 2017, http://www.unesco.org/new/en/social-andhuman-sciences/themes/human-rights-based-approach/60th-anniversary-of-udhr/unescoand-the-declaration/

${ }^{3}$ Gender and Racial Discrimination Report of the Expert Group Meeting, United Nations, accessed October 21 2017, http://www.un.org/womenwatch/daw/csw/genrac/report.htm
}

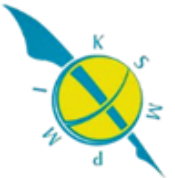


debatable issue as several traditions contradicted with what have been agreed in the UDHR. The evolved human rights issue such as racism, oppression, or gender and sexuality have created new perspective for one's community in seeing their own tradition. Even though UNHRC recently passed a resolution on "traditional values of humankind" as a vehicle for "promoting human rights and fundamental freedoms.", the fact that they also promote the rights of the new arising social issues of women and LGBT flies away from in the founding principles of universality and indivisibility enshrined in the Universal Declaration of Human Rights. ${ }^{4}$ Traditional practices often to be seen as violation of human rights as it denies the terms in UDHR and by that for some community, it threatening their identity as people who preserve their tradition. The practices that they forego for years, inherited, held as their identity, and believed integral to their sustainable livelihood. In the societies that have inherent traditional values, adherence to rituals and customs are fundamental; they create a structure of distinctiveness and provide a dimension with which citizens can face the issues of day-to-day living in a meaningful way. ${ }^{5}$ But due to their inconsistent with universal doctrine of human rights values, their tradition slowly being seen as a threat to achieving human freedom. Even though international institutions have been trying in develop connection with human rights values and traditional societies, the undeniable differences that contradict with each other still prevent mutual understanding to happen between them. One thing that can be undermined in here is that how the supposed to 'universally' accepted human rights declaration seems to be not accepted universally.

Focusing on the case study of this paper, Bride Kidnapping or to be known as alaa kachuu is the traditional practice conducted by Kyrgyz people in

4 “"Traditional Values” Code for Human Rights Abuse?', Human Rights Watch, 17 October 2012, https://www.hrw.org/news/2012/10/17/traditional-values-code-human-rights-abuse.

${ }^{5}$ Kuhn, Brittany, Universal Human Rights vs. Traditional Rights, Topical Review Digest: Human Rights in Sub-Saharan Africa, 39 
Kyrgyzstan. ${ }^{6}$ Bride Kidnapping is the act of abducting women to marry her and includes a variety of actions ranging from stage abduction for consensual marriage and use of violence for non-consensual kidnapping. In historical context, bride kidnapping is closely tied to economics, social structure, famility organization and gender stratification and has assumed many different forms and functions in other parts of the world such as Japan (Shida 1999), Turkey, and China, as well as among the Asian Hmong (Moua 1995). ${ }^{7}$ Because abducting a woman for the purposes of marrying her is not a uniquely Kyrgyz tradition, modern bride kidnapping cannot be sufficiently understood simply as an element of nomadic culture that evolved in isolation on the Central Asian. ${ }^{8}$ Even though there is no consensus among Kyrgyz people to consider alaa kachuu as 'Kyrgyz tradition', it can be traced back to ancient Kyrgyz history, when Kyrgyz males kidnapped marriageable young women from neighboring tribes in order to wipe out enemies and increase their own clans. ${ }^{9}$ In the 18 to $19^{\text {th }}$ centuries, kidnapping was the only way for a couple to get married if they could not do it for reasons of parental non-consent or issues of money. As there are variety clans in Kyrgyzstan, wedding often determines by wealth status and the compatibility of their clan. Through this, ala kachuu have been seen as a way for Kyrgyzs Men to express their will to marry the women and been acknowledge as a normal way of proposing marriage.

While Kyrgyzstan as a state has become modern and adopted external values to their understanding of emerging social issues, they also gain understanding on the Universal Declaration of Human Rights. Through that, they become conscious on the issue of discrimination that revolves around them, especially conflicted views on ala kachuu tradition. As the tradition defies with the values within UDHR, it seen as an act of violating human rights, in terms of

\footnotetext{
${ }^{6}$ Allworth, Edward. 1994. Central Asia: 130 Years of Russian Domination, A Historical Overview, 3rd edition. Durham: University of North Carolina Press

${ }^{7}$ L. Russ et al., 'Kyrgyz Bride Kidnapping', 2000, 6.

${ }^{8}$ ibid

${ }^{9}$ Russ et al., 'Kyrgyz Bride Kidnapping', 1.
} 
discrimination of women. The UDHR doctrine has widened and resistance movement of bride kidnapping act become more relevant. As part of United Nations members, Kyrgyzs Government also obliged to follows UDHR by creating a policy that align with the values. Through that, the government also taking stances with UDHR and their policy to diminish any act of discrimination in their country, including the continuity of bride kidnapping tradition. By this study case, research question that will be analyzed in this paper is how Bride Kidnapping tradition in Kyrgyzstan become stigmatized as an act of Discrimination?

\section{Conceptual Framework: Alexander Wendt's Constructivism}

To understand how Bride Kidnapping tradition become labeled as an act of Discrimination, Alexander Wendt's view on Constructivism will be used as conceptual framework align with the background of the case in this paper.

Within social theory constructivists emphasize the social construction of reality, they believe that human relations, including international relations, consists of thoughts and ideas and not essentially of material conditions or forces. ${ }^{10}$ Through the philosophy stance, the social world is not a given as it is not existed independently and creating thoughts and ideas of the people. It could not be discovered by scientific research and explained by scientific theory. ${ }^{11}$ The social world is a world of human consciousness of thoughts, ideas, and concepts of language and discourses of understandings among human beings, especially groups of human beings, such as states and nations. ${ }^{12}$ The social world is meaningful to people who understand the constructed physical entities, which signify the minds of people. The core ideational element upon which constructivists focus is intersubjective beliefs that are widely shared among people. Ideational have been view used by constructivist Alexander Wendt in their understanding of

\footnotetext{
${ }^{10}$ Robert H. Jackson and Georg Sørensen, Introduction to International Relations: Theories and Approaches, Fifth edition (Oxford: Oxford University Press, 2013), 211.

11 ibid

12 Jackson and Sørensen, Introduction to International Relations, 212.
}

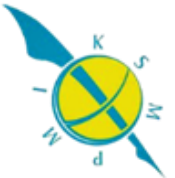


constructivism. According to the ideational view, the material world is indeterminate and is interpreted within a larger context of meaning, thus defined by ideas. ${ }^{13}$

Through this, Wendt has focused on fundamentally behavioral conception of both process and institutions by change of behavior but not identities and interests. As his case study centralized on the structure of anarchy, Wendt argues that anarchy environment has power in constitute states to accept values as their act of self-help. ${ }^{14}$ International institutions are believed can change power and interests. Wendt also taking view of several constructivists in mind, such as Joseph Nye complex learning or Robert Jervis "changing conceptions of self and interest". ${ }^{15}$ But Robert Keohane of "sociological conceptions of interests" has intrigue Wendt's view in constructivism as it asserted an important role for transformations of identity and interest in much stronger conception of process and institutions in world politics. ${ }^{16}$ Wendt emphasizes the focus of his constructivism on the social construction of subjectivity and minimize their image problem. He believes, despite important differences of cognitivists, poststructuralists, standpoint and postmodern feminists, rule theorists and structurationist, they share a concern with the basic "sociological" issue such as issue of identity. ${ }^{17}$ By that, Social structures consist in three parts: shared understandings, expectations, or knowledge that constitute the actors in a situation and the nature of their relationships. This social structure depended on ideas which in the sense of constructivism has an idealist view on structure. ${ }^{18}$

\footnotetext{
${ }^{13}$ ibid

${ }^{14}$ Alexander Wendt, 'Anarchy Is What States Make of It: The Social Construction of Power Politics', International Organization 46, no. 2 (March 1992): 2, https://doi.org/10.1017/S0020818300027764.

15 ibid

${ }^{16}$ Wendt, 'Anarchy Is What States Make of It', 4 .

17 ibid

${ }^{18}$ Jackson and Sørensen, Introduction to International Relations, 212.
}

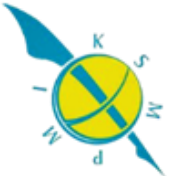




\section{Analysis}

In analyzing the changing perspective on ala kachuu act, first, we will explain how ala kachuu act being preserves as a tradition for Kyrgyzs people. Second, we will explain how Universal Declaration of Human Rights can shape Kyrgyzs people perspective on social issues. Lastly, we will connect the dot between traditional value and UDHR itself. Which by that, how UDHR change the view the tradition as discrimination act.

If we are looking on how Kyrgyzs people perceive ala kachuu as their tradition, it grounded by their understanding of the situation which develop into their norms. By historical context, the act of bride kidnapping was based on the societal conditions in Kyrgyzs area that divided different class clan and their economic situation. The requirement of marrying someone was hard as they need to stand in the same level of clan and have enough economic support to back up their family life. In that situation, Kyrgyzs become developing a way to have an easy marriage without concerning on those requirements and thus creating the act of bride kidnapping. They believe that the purpose of bride kidnapping is to have marriage easily, and it becomes something that normal to do for those who can not afford to fulfill the needs for marriage. As ala kachuu become a tradition that inherited throughout years, it also shaped the perspective of marriage between men and women in Kyrgyzstan. Men and Women in Kyrgyzstan become accustomed to romanticize the tradition act. They have been constructed by the inherited tradition and sees the act as one thing that they need to go through. By that, ala kachuu existed by ideas and thoughts from Kyrgyzs people in purpose as the only normal way in proposing women and as it inherited through generation, it has been acknowledged as part of their tradition.

In other aspects, Human rights doctrine in Kyrgyzstan not happened by forces, but through the awareness of the state and the people to obligate with the values as united nations members state. Because the declaration of Human Rights established within United Nations, as the international institution it significantly

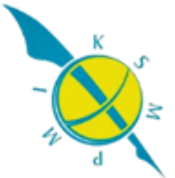


constructed the perspective on social issues in the world. Social issues such as discrimination become generalized through the declaration of Human Rights and become accepted as a threat to human freedom. Thus, any kind act that defies the principles within declaration of human rights in achieving human freedoms has been stated as an act of discrimination.

Through this, United Nations as international institution has shown that they have power to change and shape interests of the state. Human Rights doctrine has fundamentally responsible for the change conception of Kyrgyzs in their ala kachuu tradition. Through the anarchy environment, Kyrgyzstan as a state is bound to accept human rights values as act of self-help. By that, Human Rights doctrine by United Nations has spread into Kyrgyzs people and they gradually accepting the values. First, they become to understand the discrimination that stated in the UDHR and reflecting on their societal situations. As ala kachuu act consisting in kidnapping women with force, people become to understand that according to the $\mathrm{UDHR}$, it is an act of discrimination as it is violating women. Kyrgyzs women gradually expects their rights to be fulfilled as stated in the Declaration of Human Rights. Thus, ala kachuu become seen as a threat to achieving human freedom, as it considered as an act of oppression towards women.

\section{Conclusion}

Through this paper, Human Rights doctrine by United Nations and traditional values in Kyrgyzstan seems to be threat to each other despite the 'universal' labeled by United Nations. In one way, alaa kachuu contradicts with human rights values as the tradition have been inherently accepted as normal societal situations. Kyrgyzs believed that alaa kachuu as romantic act to propose and have never been considered as act of discrimination. As the tradition has been inherited through generations, it has been accepted by kyrgyzs people. In another way, Universal Declaration of Human Rights (UDHR) seen the tradition defying their principles in achieving human freedom. Thus, they acknowledge the tradition

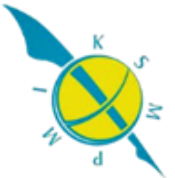


as an act of discrimination and violating human rights. Women in Kyrgyzs gradually accepting the human rights doctrine by United Nations as it fits with their conditions as someone who taking damage from being kidnapped in the name of tradition. Thus, the denial of the alaa kachuu tradition has shown to be affected by the doctrine of Human Rights by United Nations. When beforehand the tradition being acknowledge as act of proposing and being romanticized, with Kyrgyzs women aware of their values as a human within UDHR, their perspective on the tradition has changed into an act of discrimination.

\section{Bibliography}

Wendt, Alexander, 'Anarchy Is What States Make of It: The Social Construction of Power Politics', International Organization 46, no. 2 (March 1992)

Allworth, Edward. 1994. Central Asia: 130 Years of Russian Domination, A Historical Overview, 3rd edition. Durham: University of North Carolina Press Jackson, Robert H., Sørensen, Georg, Introduction to International Relations: Theories and Approaches, Fifth edition (Oxford: Oxford University Press, 2013)

Gender and Racial Discrimination Report of the Expert Group Meeting, United Nations, accessed October, 21 2017, http://www.un.org/womenwatch/daw/csw/genrac/report.html

Human Rights Watch, “Traditional Values” Code for Human Rights Abuse?', Human Rights Watch, 17 October 2012, https://www.hrw.org/news/2012/10/17/traditional-values-code-human-rights-abuse.

Kuhn, Brittany, Universal Human Rights vs. Traditional Rights, Topical Review Digest: Human Rights in Sub-Saharan Africa, 39

L. Russ et al., 'Kyrgyz Bride Kidnapping', 2000, 6.

Universal Declaration of Human Rights, United Nations, accessed October, 20 2017, http://www.un.org/en/universal-declaration-human-rights/

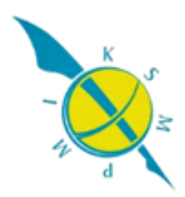


ISSN 0216-5031

$\mathrm{H}$ a I a m a n | $\mathbf{9 6}$

UNESCO and the Declaration, United Nations Educational, Scientific, and Cultural

Organization, accessed on October 20 2017,

http://www.unesco.org/new/en/social-and-human-sciences/themes/human-

rights-based-approach/60th-anniversary-of-udhr/unesco-and-the-declaration/ 